Mukaddime, 2020, 11(1), s. 97-123.

DOI: $10.19059 /$ mukaddime.609727

\title{
Türkiye'deki Suriyeli Kadınlar: Kurban ya da Sosyal Girişimci
}

\section{Emel TOPÇU ${ }^{1}$}

\section{Öz}

Bu araştırmanın amacı, kadınların Suriye'deki geçmişleri ışığında Türkiye'deki geleceklerini anlayabilmek adına, hâlihazırdaki konumlarını en çok etkileyen sosyo-politik meseleleri analiz etmektir. Bu konuda birçok araștırma yapılmıs olmasına rağmen, bunların çoğu, sağlık, şiddet, ayrımcılık, dışlanma, psikolojik ve ruhi sağlık gibi problem konularına odaklanmıştır. Oysa bu çalışma farklı bir bakış açısı ile bu kadınlara kendi adlarına, kendi tecrübeleri ve geleceğe ait kendi planlarını konuşabilmeleri için bir platform sunmuş ve veriler bu anlayış ile toplanmıştır. Bu çalışma, Suriyeli kadınlarla geçirilen beş yıllık bir beraberliğin sonunda, onların nasıl, kendilerine yardım eden gönüllü gruplarla arkadaşlık geliştirip daha sonra kendi girişimciliklerini başlattıklarını tespit etmeye fırsat vermiştir. Araştırmanın başlangıcında, Türkiye'ye ilk geldiklerinde, genelde kadınların gidip yardım kurluşlarından yardım istemesi şaşırtıcı bir tespittir. Erkekler aileleri için yardım istemekten utanmışlardır. Zira bu durum onların geleneksel aile yöneticisi olma rollerine ters düşmektedir. Suriyeli kadınlardan bazıları, yardım faaliyeti yürüten Türk kadınlardan yardım almaya başlayınca her iki grup arasında zamanla bir arkadaşlık oluşmuştur. Böylece bazı Suriyeli kadınlar zamanla Türk kadınlarla beraber, diğer Suriyeli mültecilere yardım faaliyetlerinde yer almaya başlamışlardır. Daha sonra bunlardan birkaçı kendi sivil toplum kuruluşlarını kurmuş, bu adım onları kurban olma rolünden aktif sosyal girişimci olmaya doğru yönlendirmiştir. Bu yüzden, Suriyeli kadınlardaki bu değişim ve dönüşüm sürecini analiz etmek üzere bu çalışmada teorik çerçeve olarak Amartya Sen ve Martha Nussbaum'un geliştirdikleri Kapasite Yaklaşımı (Capability Approach) kullanıımıştır.

Bu çalışma sosyal, siyasi, kültürel ve toplumsal cinsiyet alanlarında daha ileri seviyede yeni araştırmalar yapmaya kapı açacak olması bakımından önem arz etmektedir. Çalışmada veriler katılımcı gözlem, derinlemesine mülakat, odak grup görüşmesi gibi nitel yöntem araçları ile toplanırken, veri analizleri Kapasite Yaklaşımı çerçevesinde hermeneutik yöntemle yapılmıştır.

1 Prof. Dr. Emel TOPÇU, Hasan Kalyoncu Üniversitesi iisBF Siyaset Bilimi ve Uluslararası iliş̧kiler Bölümü, emel.topcu@hku.edu.tr, ORCID ID: 0000-0003-4606-5961. Bu makalenin yazımında Suriye'deki kanunlara ulaşmamda ve Arapça ifadeleri tam olarak anlamlandırmakta büyük yardımları olan Dr. Rida Anis'e teşekkürü bir borç bilirim. 
Anahtar Kelimeler: Suriyeli Kadınlar, Mülteci, Sosyal Girişimci, Aile

\title{
Syrian Women in Turkey: Victim or Social Entrepreneur
}

\begin{abstract}
The goal of this research is to investigate some of the most effective sociopolitical issues which Syrian women refugees currently undergo in Turkey, shedding light on few crucial backgrounds from their past in Syria, passing to their future prospects. Even though much research has been conducted in this field, which were more focussed on problems such as health, violence, inclusion and exclusion, isolation, psychological and mental issues, ... etc, this study has a different approach; we want these women to speak about their own experiences and reflect their own plans. During our five years of research, we have understood that there has been a very unique and interesting relashionship gradually developing between Syrian refugees and some humanitarian aid-organizations and volunteer groups. To our surprise, we come to know that it was the Syrian women, and not the men, who first initiated the contact with these organizations and groups. Men, it seems, were humiliated to ask for help for their families. Some of these Syrian women who started getting some aid, especially from the volunteering Turkish ladies, began building a friendship with them. This led to such things as Syrian women beginning to volunteer to work together with the volunteering Turkish ladies to help other Syrian refugees. Later, few of them were even able to establish their own NGO's. This process has definitely changed them from vulnerable victims to active social agents. Impressed by this phenomenon, we decided to use Amartya Sen's and Martha Nussbaum's social agent and capability approach as a suitable theoretical framework for our study.

This study is significant for two reasons. First, it benefits Social, Political, Cultural, and Gender Studies to build up and produce further researches and outcomes. Second, it helps political decision-makers achieving a more functional participative society. We use the qualitative method to collect our material and then analyze them by the hermeneutical method.
\end{abstract}

Keywords: Family, Refugees, SocialAgents, SyrianWomen.

\section{Extended Abstract}

The Syrian War which started in 2011 has dramatically changed Syria, both politically and demographically, causing many influxes to the neighboring countries. Turkey, by itself, has so far received more than three-millionand-five-hundred immigrants, males more than females. Women's immigration causes more fundamental changes than men's.

This research puts the Syrian women under focus, right at the center, by letting them articulate their own experience, agenda, and goals without any previous plans for the research but to let them speak for themselves 
as completely independent subjects and not objects. Amazingly, we come to realize that it is the women who are more active, socially speaking, and thus more willing to struggle to ask for aid for their children and families to survive, specially in cases of need and immergency, such as the time of war. Occasionally and gradually, some exceptional women proven to become successful activists helping the victimized of their own community inspiring other Syrian women to become social agents.

Since our goal is to provide an authentic picture of some crucial sociopolitical issues concerning Syrian women refugees, we decided to fathom the depth of these issues to provide a better undestanding of the case. For this reason, we have chosen the Qualitative Methodology. It is valuable in the sense that it provides rich descriptions of complex phenomena and tracks unique or unexpected situations. In fact, it helps explaining events by doers of different statuses and roles, giving voice to those who were never given a chance to speak or to be heard before. Focus-group discussions and in-dept interviews are two types of the qualitative data collection that we are frequantly using in this paper. Focus-group discussions first inspire the ideas of the participants when they start communicating. This leads to produce a new type of thinking. We wanted these women to speak for themselves as authenticated subjects rather than reseacrh objects. Therefore, we have chosen the above-mentioned methology to have a buttom-up approach rather than a top-down one. As researchers, in fact, we developed a kind of friendship with some of them, joining their weddings, attending some funerals, having picnic together, inviting each other for feasts, ... etc. After this spontanous participative observation, the idea of conducting a research came to our mind. So, we started to add in-depth interviews and focusgroup discussions to our participative observation. However, it was not that easy because we needed a channel to contact them and develop trust by time so these women can more and more unfold their personal experiences.

In this study, the Capability Approach developed by Amartya Sen and Martha Nussbaum was used as theoretical background. The Capability Approach describes the choice they make from the possibilities (capability) in the free environments offered to them in order to achieve a life that they reason to value with their own minds. The more alternative opportunities are offered to reach the life they find valuable, the more comfortable they will be able to choose. As the opportunities, capability decrease, the choice opportunity will decrease.

The Capability Approach is a framework of thought, a normative tool rather than a fully defined theory, and does not answer all normative questions. It is an approach that seeks to answer the question of what people have achieved with the possibility of that environment in their own environment, and what they could have achieved if there were other opportunities, and in this context, it seeks the answer to the way in which people's conditions should be changed best.

The key findings of the study are; The life in Turkey for Syrian women is quite different and harder than the one in Syria because it gives them some additional responsibilities. Women state that they are like men here 
because of their responsibilities such as shopping, paying bills, making money for the family, taking additional obligations outside the home for the family. This situation changes the gender roles they are accustomed to. On the other hand, there are some changes in families and social roles as Syrian men cannot fulfill their traditional roles as in Syria. This is an indication that gender roles changes have started in the family and society among Syrians.

Another important issue is that the Syrian women become more active in the society they live in, especially with the encouragement of Turkish women who help Syrian women and children. Over time, they started building their own NGOs. These social entrepreneur Syrian women had the opportunity to help other Syrian women and children in need. They organize educational activities for Syrian women and children. All these efforts ultimately help the two communities live more harmoniously. 


\section{Giriş}

Suriye savaşı hem Suriye'de hem de çevre ülkelerde politik ve demografik olarak büyük değişikliklere yol açan önemli bir olay olarak 2011 yılında başlamıştır. Türkiye en çok Suriyeliyi kabul eden bir ülke olarak şu an diğer mültecilerle birlikte dört milyon civarında mülteciyi barındırmaktadır. Bu miktar 2011 yılından sonra hızlı bir şekilde ülkeye giren insan sayısına işaret etmektedir. İlk yıllarda genelde aileler gelirken, son yıllarda gelenlerin yapıları değişmeye başlamıştır. Şu an Türkiye'de Suriyeli erkek sayısı kadın sayısından daha fazladır. Bu durum, askerlik yapabilecek bütün erkeklerin askere zorla alınıp rejim tarafından savaştırılmak istenmesinden dolayı gelişmiş bir olaydır. Erkekler inanmadıkları, karşı çıktıkları bir rejim için savaşmak yerine ülkeyi terk etmekte çözümü bulmuşlardır. Ancak son yıllarda, Suriye'de kadın sayısının çok fazla olması, özellikle genç kadınların da yavaş yavaş herhangi bir erkek eşliği olmadan, ama daha önce buraya gelmiş akrabaları yardımı ile kendilerine başka bir gelecek arama düşüncesi ile göç ettiklerine şahit olunmaktadır.

Geldikleri ilk yıllarda, bir taraftan misafir olarak değerlendirilip, ihtiyaçları karşılanırken, diğer taraftan kendilerini burada nasıl konumlandıracaklarını bilemedikleri karmaşık bir hayatın içindeydiler. Birçok Türk sivil toplum kuruluşu ve özellikle herhangi bir sivil toplum kuruluşuna dâhil olmayan kadınlar kendi aralarında sosyal medya üzerinden örgütlenerek yeni gelen Suriyelilerin bütün ihtiyaçlarını karşılamaya çalıştılar (Topcu, Female Leadership in the Framework of Crises Management within the Scope of Aid to the Syrians (An Example from Ankara), 2018). Türkiye Suriyelileri hukuki olarak mülteci statüsünde kabul edemediği için ilk başta "misafir" kavramı altında bir kabul gerçekleştirmiştir. Fakat savaşın bitmemesi, gelenlerin her geçen gün artması ile bu duruma bir çözüm bulmak adına Yabancılar ve Uluslararası Koruma Kanunu (YUKK) (YUKK, 2013) çıkarılmış ve bu kanun çerçevesinde Suriyeliler "Geçici Koruma" altına alınmışlardır. Böylece Suriyeliler mülteci olarak kabul edilmemekle beraber bir mültecinin sahip olduğu hemen bütün haklara sahip olarak savaş bitene kadar geçici koruma altındadırlar. Suriyelilerin, Türkiye'deki resmi durumları mülteci olmamasına rağmen, hakları ve konumları bakımından mülteci durumunda olduğundan, makalede Suriyelilerden mülteci kavramı kullanılarak bahsedilecektir.

Kadınların göçü hem göç esnasında hem sonrasında erkeklerin göçüne göre çok daha temel değişiklikler içerir ve oluşturur. illk göç çalışmaları genelde erkekleri temel alarak yapılan çalışmalardır. ilk başlarda göç araştırmalarında erkekler temel alındığı için kadın konusu geri plana itilmiş ve daha çok problem alanları olarak araştırma konusu içerisine girmiştir. Göç içinde kadın konusunu çalışmak çok daha sonraları gündeme gelmiştir (Fincher, Foster, \& Wilmot, 1994). $\mathrm{Bu}$ ilk çalışmalarda kadınlar erkeklere, eş, kız çocuğu, anne olarak bağımlı unsurlar olarak ele alınmışlardır (Boyd, 1975) (Moroksavic, 1984). 
Araştırma alanlarına feminist anlayışın yavaş yavaş etki etmesi ile birlikte kadın konusu yan alan olmaktan çıkıp asıl araştırma unsuru olarak ele alınmaya başlanmıştır. Bu anlayış çerçevesinde bu çalışma, Suriyeli kadınları odağa almış ve kendi kendilerini özgürce ve istedikleri gibi ifade etmelerine zemin hazırlayarak onları nesne değil obje olarak değerlendirmiştir. Araştırmamız sırasında, özellikle savaş, afet gibi acil durumlarda, çocukları ve aileleri için tehlike oluştuğunda, hayatta kalmak adına, kadınların çocukları ve aileleri için diğer aile fertlerine göre daha aktif bir şekilde girişimde bulundukları, yardım için kapı kapı dolaştıkları tespit edilirken, bazı kadınların, bu girişimlerini daha ileriye götürerek sosyal girişimci olma yolunda adımlar atmaya başladıkları tespiti yapılmıştır.

\section{Yöntem}

Bu çalışmanın amacı Suriyeli mülteci kadınların sosyo-politik durumlarının otantik bir resmini çıkarmak olduğu için, araştırma sorularına derinlemesine cavaplar bulmaya çalıştık. Bu çerçevede nitel çalışma bir konunun derinlemesine anlaşılmasına imkân sağladığı için bu çalışmada nitel yöntem kullanılmıştır. Nitel yöntem özellikle karmaşık ilişkiler bütünü olan, çok özel bir yapı arz eden ya da beklenmedik bir durumla oluşan yeni yapılanmaları anlamak için elverişli bir yöntemdir. Günümüz dünyasında, sosyal durumlarda, yerel, millî ve küresel düzeyde sürekli değişim yaşanmaktadır. Asıl mesele bu değişimin oluşma aşamalarında bizim herhangi bir müdahale etme imkânımızın, ya da bu değişimin bizi nereye götürdüğünü anlama şansımızın olup olmaması ile ilgilidir. İnsanların farklı tecrübeler çerçevesinde geliştirdikleri ilişkileri gittikçe karmaşıklaşmakta, bu ilişkilerle oluşan sosyal yaşamla ortaya çıkan kurumlar da bu karmaşıklıktan nasibini almaktadır. Bu çerçevede ileride gelişecek yeni durumlara eskiden geliştirilmiş bu ilişki kalıplarının ve kurumsallaşmanın nasıl uygulanabileceği ya da bu değişimin hangi yöne gideceğinin önceden tespiti zorlaşmaktadır. Ama bu değişim ile birlikte yapılan “Eylem Araştırması” dediğimiz türdeki araştırma, değişim süreçlerinin uygulanması sırasında ortaya çıkan bilgilerin tespitinde önemli bir araç sunar. "Eylem Araştırması" yöntemi sosyal bilimler araştırma tekniklerini, katılımcıların pratik günlük hayat faaliyetlerine uygulayarak kişilerin kendilerini güçsüz bir nesne değil, aktif üyeler olarak algılamalarını sağlar (Somekh, 2006).

Suriyeli kadınların hayatlarına tanıklık edilen beş yıllık araştırma dönemi boyunca "Eylem Araştırması" yöntemi uygulanmış ve ayrıca nitel çalışmanın önemli veri toplama araçlarından olan katılımcı gözlem, odak grup görüşmeleri ve derinlemesine mülakat yöntemlerinden de yararlanılmıştır. Odak grup görüşmeleri, gruba katılanlar arasında, birbirleri ile konuşmaya başladıktan sonra yeni fikirlerin oluşmasına ve onların formüle edilmesine imkân veren bir ortam sunar. Bu yöntemle biz araştırmacılar da olayın değişik boyutlarını daha iyi anlamaya, genelde açık açık konuşulmaya pek cesaret edilemeyen hassas, birbirine tamamen zit konulara dokunmaya, normalde çatışmalara sebep 
olabilecek konuların güvenli bir ortamda rahatça birbiri ile karşılaşmasına imkân veren ortamlar yakalarız (UNFPA, 2010).

Bu çalışmada araştırma çerçvesinde görüşme yapılan kadınlar bir nesne değil özne olarak değerlendirilmiş, onların aynı zamanda araştırmayı şekillendirmelerine fırsatlar sunulmuş, böylece tabandan tavana bir yaklaşım izlenmiştir. Araştırma boyunca görüştüğümüz kadınlarla arkadaşlıklar geliştirilmiş, düğünlerine, cenaze törenlerine katılınmış, beraber piknik yapılmış, özel günlerimizde karşılıklı olarak davetler gerçekleşmiş, böylece gelişen yeni durumlarla yeni çalışmalar içine girilmiş, beraber yeni projeler geliştirilmiştir. Bütün bunları oluşturabilmek için birbirimize karşılıklı olarak güvenmemiz gerekmekteydi. O yüzden araştırma önce katılımcı gözlem şeklinde başlayıp daha sonra yavaş yavaş derinlemesine mülakat ve odak grup görüşmeleri şeklinde devam etmiştir.

Bu çalışmaya ilk olarak Ankara'da Suriyelilere yardım için bir araya gelen bir kadın grubu olan "Gönüllüler Grubu”nun çalışmalarına 2014 yılında katılarak başlanmıştır. Suriyelilerin yoğun olarak Ankara'ya gelmeleri 2014 yılında başlamış ve "Gönüllüler Grubu", Nezahat Albay önderliğinde hızla sosyal medya üzerinden organize olarak, özellikle kadın ve çocuklar olmak üzere, aile bazlı olarak Suriyelilere, bütüncül bir yaklaşımla, onların her türlü ihtiyaçlarını gidermek için yardım eden bir oluşum haline gelmiştir (Topcu, E. Kurtulmuş, S., 2017).

Araştırmanın ikinci durağı Diyanet Vakfı'nın bir kuruluşu olan, Sosyal Destek ve Eğitim Merkezi'nde "SODEM" 2016-2017 yıllarındaki merkeze gelen Suriyelileri gözlemleme, onlarla yine derinlemesine mülakatlar ve odak grup görüşmeleri ile veri toplama şeklinde gerçekleşmiştir. Bu çalışmalar sırasında kurumdaki iki asistan arkadaş ile yaptığımız her haftaki değerlendirme toplantıları olayı daha detaylı olarak kavramama yardım etmiştir.

Bu çalışmalar sırasındaki üçüncü kanal ise Gaziantep’te Suriyeli kadınların Türk sivil toplum kuruluşlarındaki kadınların desteği ile kurduğu BELKIS derneğindeki, "Geçici Eğitim Merkezi” GEM okullarında öğretmen olarak çalışan kadınlar olmuştur. Araştırma alanındaki dördüncü kanal, KALMIREC Hasan Kalyoncu Üniversitesi Göç Araştırmaları Merkezinde Suriyeli kadın sivil toplum kuruluşları ile yapılan ortak çalışmalar ve özellikle "Mezopotamya'da Kadın Olmak" projesi sırasındaki çalışmalar olmuştur.

Sosyal bilimlerde yapılan araştırmalarda en çok tartışılan konulardan biri araştırmacının konumudur. Araştırmacı grubun kendi içinden olsa başka eleştiriler, dışından olsa başka eleştiriler söz konusudur. Bir araştırmacı olarak benim bu araştırmadaki pozisyonum, hem içerden hem de dışardan olarak değerlendirilebilir. Suriyeli grubun içinden gelmediğim için "dışardan" olarak değerlendirilirken, çok uzun yıllar yurt dışında göçmen bir kadın olarak yaşamış olmam bakımından "içerden" olarak değerlendirilmeme imkân sağlamaktadır. Aslında içerden ya da dışardan olma kavramı bu çerçevede izafi bir kavramdır 
(Phoenix, 200) (Naples, 1996). Bir grupla aynı kültür ya da milliyetten gelmek araştırmacıyı otomatik olarak o gruptan yapmayabilir. Bir araştırmacı araştırma boyunca kendini hem içerden hem dışardan pozisyonlarda bulabilir, bu iki pozisyon arasında gidip gelmesi aslında onun meseleyi daha iyi anlamasına yardım edebilir (Dwyer, S. C. \& Buckle, J. L, 2009).

Bu çalışma esnasında sadece Suriyeli kadınlarla mülakatlar ya da odak grup görüşmeleri yapılmayıp onlarla çalışan yerli görevlilerle de görüşülmüştür. Ayrıca, Ankara'da Suriyelilerin yoğunluklu yaşadığı yerlerde komşu yerli kadınlarla görüşmeler yapılmıştır. SODEM'deki asistanlarla 6 değerlendirme toplantısı, Suriyeli kadınlarla 4 ve erkeklerle 1 olmak üzere toplam 5 odak grup görüșmesi ve 27 Suriyeli kadın ve 13 Suriyeli erkek toplam 40 Suriyeli ile derinlemesine mülakat yapılmıştır. Ayrıca Suriyelilerle çalışma yapan 5 Türk öğretmen ile de detaylı bir şekilde mülakat yapılmıştır. Görüşme yapılan kişiler 18-58 yaş aralı̆ıında, ilkokulüniversite eğitim seviyesine sahip olup farklı sosyal ve ekonomik çevrelerden gelmektedirler.

Görüşmeler esnasında Arapçayı ana dili olarak kullanan ya da o derecede bilen danışmanlarla beraber çalışılmıştır. Bazı Suriyeliler Ingilizceyi çok iyi derecede bildikleri için o kişilerle iletişim ve görüşmeler Ingilizce olarak yapılmıştır. Görüşmelerin büyük çoğunluğu görüşülen kişilerin izinleri ile kayıt altına alınmış ve daha sonra bu görüşmeler kişilerin bilgisi dahîlinde deşifre edilmiştir.

Görüşmeler esnasında durumları ile ilintili bazı hassas konulara çok dikkatle değinilmiş o konuda konuşmak istemediklerinde saygıyla karşılanmıştır. Savaş sırasında cinsel taciz ve tecavüz, ev içi şiddet, çok eşlilik, kız çocuklarının erken evlendirilmesi gibi konular belirli bir güven içerisinde dikkatlice ele alınmıştır. Katılımcıların birçoğu bu konularda konuşmak istememiş, bu durum tarafımızdan anlayışla karşılanmıştır. Ayrıca katıımcıların büyük çoğunluğu, Suriyeli kadın mülteciler olarak sadece bu konularla ilintilendirilmekten yorulduklarını o yüzden daha fazla öyle değerlendirilmek istemediklerini belirtmişlerdir.

Normal görüşmenin akışı içerisinde evlilik yaşlarını sorduğumda genelde on yedi, on sekiz olarak belirtmişlerdir. Soruların ve sohbetin ilerlemesi ile çocuklarının yaşları ve şimdiki yaşları ortaya çıkınca gerçek evlilik yaşlarını hesaplama imkânı olmuş ve genelde çok küçük yaşlarda hatta onüç, ondört yaşlarında evlendikleri ortaya çıkmıştır. Gerçek evlilik yaşlarının ne olduğu hesaplama sonucu belirttildiğinde, itirafta bulunarak, aslında Suriye'de erken evliliğin kanuni ve geleneklere uygun olduğunu, ama Türkiye'de evlilik yaşının on sekiz olması dolayısı ile yanlış anlaşılır ya da Türkiye'de kabul görmezler diye öyle söylediklerini belirtmişlerdir (SK9, 2017). Bu tespit araştırma yaparken, kültürel farklar ve kişilerin yeni geldikleri ülkelerde kabul edilmeme tereddüdü ile bazı gerçekleri saklama eğiliminde olabilecekleri gerçeğini ortaya koymuştur. 
Araştırmamız eylemsel araştırma yöntemleri çerçevesinde geliştiği için araştırmamızın bazı önceden tahmin edilemeyen sonuçlar doğurduğu da tespit edilmiştir. Bazı Suriyeli kadınlar Suriye'deki hayatları konusunda pembe tablolar çizmişler, anlatılanların abartılı gelmesine rağmen onların kendi beyanları olduğu için olduğu gibi kabul etmek durumunda kalınmıştır (SK2, Suriye'de ve Türkiye'de Hayat, Suriyeli Kadın 2, 2017). Ama yapılan mülakatlardan bir kaç gün sonra, SODEM'de psikolog olarak çalışan ve Arapçası anadili gibi olan asistanım, mülakattan sonra bazı kadınların vicdan azabı duyarak kendisinden danışmanlık için randevu aldıklarını belirtmiştir. Oysa başlarda sürekli sınıflara gidip herhangi bir problem olduğunda danışabileceklerini bildirmesine rağmen Suriyeli kadınlar bu fırsatı pek fazla kullanmamışlardır. Fakat araştırma çerçevesinde yapılan mülakatlarda Suriye'deki hayatları hakkında pembe tablolar çizdikten sonra, bu şekilde "mış" gibi yapmanın kendilerini rahatsız ettiğini fark edip gerçeği konuşmak üzere psikologdan randevu almışlardır. Araştırma için yapılan mülakatlar onlara iyi gelmiş, yaşadıkları travmayı profesyonel bir şekilde ele alıp değerlendirmek için yeni bir yola girmelerine vesile olmuştur (TKÖ4, 2017) (D3 \& Toplantısı, 2017).

Bu makaleyi yazarken kişisel hakların korunması çerçevesinde isimler değiştirilerek kullanılmış ve referans verirken SK1 (Suriyeli Kadın 1), D1(Değerlendirme Toplantısı 1), TKÖ1 (Türk Kadın Öğretmen 1), TEÖ1 (Türk Erkek Öğretmen 1), SKOG1 (Suriyeli Kadın Odak Grup Görüşmesi 1) SEOG1 (Suriyeli Erkek Odak Grup Görüşmesi 1) gibi kısaltmalar kullanılmıştır.

\section{Teorik Çerçeve}

$\mathrm{Bu}$ çalışmada teorik olarak Amartya Sen ve Martha Nussbaum'un geliştirdikleri “Kapasite Yaklaşımı” kullanılmıştır. Kapasite Yaklaşımı, kişilerin kendi akılları ile değer (reason to value) verdikleri bir hayata ulaşabilmek için onlara sunulan özgür ortamlardaki imkânlar (kapasite) içinden yaptıkları seçimi anlatmaktadır. Bu yaklaşıma göre, kişilere, kendileri adına değerli buldukları hayata ulaşabilmek için ne kadar çok alternatif fırsatlar sunulmuşsa, o kadar rahat seçim yapabileceklerdir. İmkânlar (kapasite) azaldıkça seçim şansı da azalacaktır. Bunun yanında bazı insanlar o kapasiteyi kendileri dar çevrelerinde bile olsa oluşturabilmektedirler (Sen, 1981). “Kapasite Yaklaşımı”nın en önemli unsuru olan "Beşeri Sermaye" olarak adlandırılan terim ile anlatılmak istenen şey ise, sosyal çevrenin (değerler, kurallar, ilişki ağları, sosyal faaliyetler) insanların genel olarak refahını etkilediği üzerinedir. Bu fikir sosyal ekonomistler ve "Kapasite Yaklaşımı" tarafından da kullanılmıştır. Sosyal ekonomistler çok önceden sosyal çevrenin insanların seçimlerini ve kararlarını etkilediğini tespit etmişlerdir. Aynı şekilde "Kapasite Yaklaşımı" da insanlar arasındaki sosyal etkileşimin insanların en merkezi kapasitesi olduğunu belirtmektedir (Nussbaum, 2000). Çalışmalarının temelini eşitsizlik ve fakirlik üzerine kuran ve bu çerçevede her ikisi ile de en uygun mücadele araçlarını geliştirmeye çalışan Amartya Sen'e 
göre, sosyal girişimci (agent) kendi sosyal ağları tarafından belirli bir şekilde donatılmışıır. Bir başka deyişle, "Beşeri Sermaye" kişinin imkânlarını, kapasitesini artıran bir unsurdur. Amartya Sen'in “Kapasite Yaklaşımı” özellikle fakirlik, yokluk durumlarında Beşeri Sermayenin önemini değerlendirme, açıklama bakımından önemli bir çerçeve sunmaktadır. Amartya Sen'in “Kapasite Yaklaşımı”nın anahtar kavramları, işlevsellik ve kapasitedir. İşlevsellik ile kişinin o zamana kadar yaptıkları, hayatta ulaştığı yer kast edilmektedir. Şimdiye kadar neler başarmıştır, sağlığı, barınması nasıldır, özgürce hareket edebilmekte midir, eğitime ulaşımı ne durumdadır gibi göstergeler işlevselliği anlatmak için kullanılır. Kapasite ise, eğer bu kişi başka hayat şekillerini seçme şansına sahip olsaydı neler başarabilirdi soruları ile ilgilenmektedir. Mesela bir insana bulunduğu yerdeki hareketliliğini artırabilmesi için bisiklet verseniz, bu kapasite artıımı eylemi, o kişinin şahsi fiziki durumu ve bulunduğu yerdeki yolların durumu ile de yakından ilintili olarak kişinin kapasitesini artırmaya yetmeyebilecektir. Eğer kişi çok yaşlı ise, bisiklete binmek için bir engeli varsa, yollar bisiklet sürmeye uygun değilse kapasite artırımı için bisiklet vermek uygun bir seçenek olmayacaktır. Aynı şekilde kişiye hayatını sürdürmesi için yiyecek veriyorsanız, yine bunun kapasite artırımına etkisi, kişinin biyolojik ve kültürel durumu ile yakından bağlantılıdır. Eğer metabolik bir problemi varsa, belirli hastalıkları var, ya da o yiyeceğe alerjisi varsa, ya da kültürel olarak belirli yiyecekleri yemiyorsa, Müslüman insanlara domuz eti olan beslenme paketleri veriliyorsa bu durum kapasite artırımına etkili olmayacaktır (Kuklys, 2005). Bu yüzden kapasite artırımı, kişilerin özel durumları göz önünde bulundurularak, kendi rıza ve istekleri dahilinde yapılmalıdır.

Amartya Sen'in en temel işlevsellik örnekleri; hayatta olmak, sağlığının yerinde olması, başının üstünde bir dam olması, özgürce hareket edebilmek, kendi kendine ve başkalarına saygısı olmak, sosyal hayata katılmak şeklinde özetlenebilir. Bunlara tabii ki bir sürü başka göstergeler ekelenebilir. İşi olmak, eğitimli olmak vs. gibi. Kapasite yaklaşımı iki seviyede uygulanmaktadır: 1Hâlihazırdaki konfor seviyesi ve eğer 2- imkânlar artırılsaydı ulaşabileceği konfor seviyesi (Sen, 1981).

Sen, kişilerin imkanlarının gelişmesi için bu iki seviyeyi tespit etmiş ama, kişileri geliştirici asıl unsur olarak özgürlüğe odaklanılması gerektiğini belirtmiştir. Burada kast edilen özgürlük, kişilerin kendilerince değerli bir hayat sürebilmeleri için, kendi istekleri ile, kitap okuma, çalışma, siyasi olarak aktif olma ya da sahip oldukları değerlerin (sağlıklı olma, okuryazar olma, vb.) kıymetini bilme gibi durumları bilinçli olarak seçebilme ve o doğrultuda çalışmaları şeklinde anlaşılmalıdır. $O$ yüzden birinci durumu tespit edebilmek için, kişilerin sadece gelirleri nedir ve bu gelirle neler alıyorlar kısmına değil, neler yapabiliyorlar kısmına odaklanmak gereklidir (Robeyns, 2003). O yüzden önce hâlihazırdaki konfor seviyesi bahsedilen göstergeler ile ölçülür ve bulunduğu şartlar göz önünde bulundurularak hangi imkânlar sağlanacak olursa kişinin işlevselliğinin, böylece yaşam konforunun artacağı belirlenir. 
Amartya Sen'in bu yaklaşımı, fakirliğin derecesinin tespiti ve o insanlara fırsat verilse bu durumdan nasıl kurtulacakları üzerine geliştirilmiş olup, daha sonra Batı'da, kadın erkek eşitsizliğini analiz etmek ve bu duruma çare aramak için de uygulanmaya başlanmıştır. Biz de bu yaklaşımı, göç etmek zorunda kalan, bu çerçevede durum değişikliği yaşayan Suriyeli kadınların kapasite gelişiminin en uygun nasıl olabileceğini hem kendi toplumlarında hem de yeni geldikleri Türkiye'deki durumlarını anlamak için analiz aracağı olarak kullanacağız. Bu yüzden bu çalışmada Suriyeli kadınların önce hâlihazırdaki konfor durumlarını anlamak için onların Suriye'deki ve Türkiye'deki hayatlarına bakılmıştır. Bu çerçevede bulgular ortaya çıkarılmış ve tartışma bölümünde bu konfor seviyesinin nasıl daha artırılabileceği üzerinde durulmuştur.

\section{Bulgular}

\section{Savaş Öncesi Suriye'de Hayat}

Suriyeli kadınların Türkiye'deki hayatlarını anlayabilmek için onların Suriye'deki hayatlarına, evlilik, boşanma, eğitim, iş hayatı ve sosyal hayat gibi konuları içine alan sosyo-politik çerçeveden bakmak faydalı olacaktır. Konuya önce Suriye'deki hukuk sistem ile başlayacak olursak, bunun Osmanlı, Fransız ve İslami hukuk sisteminden etkilendiği görülmektedir. Özellikle evlilik, miras, boşanma ve çocukların velayeti gibi medeni hukuk alanına giren konular dini (İslam, Hristiyan ve Yahudi) hukuk tarafından şekillendirilmiştir. Suriye'deki Sünni çoğunluk için İslam hukuku kuralları geçerli iken, diğer azınlık gruplar olan Dürzi (İslam içinde olup olmadığı tartışmalıdır), Yahudi ve çeşitli Hristiyan gruplar için de kendi dinleri çerçevesinde belirlenmiş hukuk kuralları geçerlidir (Eijk, 2014). Dini grupların oranı hakkında herhangi bir istatistik olmamasına rağmen, Sünnilerin \%75, Sünni olmayan Müslümanların \%12, Hristiyanların \%10, ve geri kalanların \%4 olduğu tahmin edilmektedir (Akdemir, 2000). Suriye'de farklı dinlerden insanların birbiri ile evlenmesi hem hukuken yasak hem de sosyal olarak tabudur. Evlilik dini hukuk içerisinde düzenlendiği için farklı dinlerden insanların birbiri ile evlenmesi mümkün değildir. Evlilik yaşı medeni Hukuk'un 16. maddesine göre kadınlar için on yedi, erkekler için onsekizdir. Fakat bunun yanında aynı kanunun 18. maddesine göre hâkim evlenme yaşını aşağı düşürebilmektedir (Qanoon Ahwaal Shakhsiyyeh, Book 1: Marriage, 2019). Hâkim kararına göre bu yaş erkekler için onaltı ve kızlar için de onüç olabilir. Özellikle kırsal kesimlerde kızlar için onüç yaş ve üzeri evlilikler sıklıkla rastlanan bir durumdur. Şehirlerde ise bu yaş genelde onaltı civarıdır. Suriye'de hemen bütün evlilikler görücü usul (taklidi) ile gerçekleşmektedir. Gelenkesel olarak evlenildiği için evliliklere aile karar vermekte o yüzden çok genç kadınlar yaşlı erkeklerle de evlendirilebilmektedir. Kadınların evlenmesi yirmibeş yaşını geçtikten sonra 
zorlaşmakta bu yaştan sonra genelde kendilerinden çok yaşlı erkeklerle ve ikinci eş olarak evlenmektedirler (SK5, Suriye'de ve Türkiye'de Hayat, 2017) (SK6, Suriye'de ve Türkiye'de Hayat, 2017) (SK7, Suriye'de ve Türkiye'de Hayat, 2017) (SK8, Suriye'de ve Türkiye'de Hayat, 2017) (SK9, 2017)(SK10, 2017).

Suriye'de çocukların kimlikleri doğduklarında çıkmamakta onlar ilk olarak önce aile defterine (Daftar Aiyleh) kayıt edilmektedirler. Çocuklar ondört yaşına girdikleri andan itibaren bir yıl içinde kimlik kartı (Hawiyyeh) için aile müracaat etmektedir (Qanoon, Al-Bitaqah Ash-Shakhsiyyeh Aj-Jadeed Madde 1, 2003) (SK8, Suriye'de ve Türkiye'de Hayat, 2017). Kanada Göç ve iltica Bürosu'nun 1 Şubat 1998 tarihinde, Suriye'nin Washington DC'deki elçiliğinden aldığı bilgilerle de bu durum teyit edilmiştir. Büro, elçilikten aldığı bilgiler çerçevesinde bu kimliği alan kişinin artık nelere yetkili olduğuna şu şekilde yorum yapmaktadır: Bu belge kişi için banka hesabı açabileceği, mahkemeye çıkabileceği, para transferi yapabileceği, evlenebileceği gibi bir yetişkinin yapabileceği günlük işleri için bir yetki belgesi gibidir. Bu çerçevede, Suriye'de bir insanın kimlik alması, aile defterinden (Daftar Aiyleh) çıkıp bağımsız hâle gelmesi, böylece de evlenebileceği anlamına gelmektedir (Refworld, 2019). Aile defterinde dört ayrı bölme olup aile reisi olarak erkeğe dört eşe kadar evlenme imkânı vermektedir (Ministry of Interior, Syrian Arab Republic, 2019).

Boşanma (Talaq) meselesine gelince, erkekler için çok kolay olan boşanma meselesinin kadınlar için bazı şartlara bağlandığı görülmektedir. Bu şartlar Qanoon Ahwaal Shakhsiyyeh (Medeni Kanun), 2. Kitap Boşanma bölümünde madde 85-120 arasında şu şekilde düzenlenmiştir: Kocasının, kendisinin önceden bilgilendirilmediği bedensel ya da ruhi, iyileșmeyecek bir hastalığı varsa, üç aydan fazla süre için kadının nafakasını sağlamamışsa, bir yıldan fazla bir süredir hapiste ya da kendinden haber alınamıyorsa ya da kocasının kendine kötü davrandığını ispatlayabiliyorsa hâkime başvurup boşanma talebinde bulunabilir (Qanoon, Qanoon Ahwaal Shakhsiyyeh, 2019). Kadınlar bu izne rağmen mahkemeye başvursalar bile süreç çok yavaş işlemektedir ve sosyal olarak da boşanma kabul gören bir durum değildir.

Ankara'da 2014 yılında karşılaştığım sonra İsveç'e göçen Fatima, Suriye'de çok mutsuz bir evlilik geçirmesine ve üstelik terzilik yaptığı için ekonomik olarak da bağımsız olmasına rağmen boşanamadığını ama Türkiye'ye geldikten sonra kocasından boşanmaya cesaret edebildiğini anlatmıştır. Suriye'deki boşanma istatistikleri de bu durumu göstermektedir. Boşanma oranı binde 0.73'dir (Divorce Statistics, Syria 2002, 2002).

Çocukların velayeti Medeni Hukuk'ta yapılan 2003 yılındaki düzenlemeye göre erkek çocuklar için onüç yaşına kadar, kızlar için onbeş yaşına kadar anneye, bu yaştan sonra velayet babaya verilmektedir. Medeni Kanun 2. kitap boşanma bölümünde madde 139-161 arası düzenlenmiş kurallara göre eğer anne çocukların velayetini almak istemezse çocuğa baba ya da babanın ailesi veya annenin ailesi, (birçok değişik durumlara göre) bakmak zorundadır. Bütün bunlara rağmen 
çocuğun velayeti anneye verilse bile çocukların masrafları babaya aittir (Qanoon, Qanoon Ahwaal Shakhsiyyeh, 2019). Bunlar kanun maddeleri olmasına rağmen, kültürel olarak çocukların velayeti babaya, baba yoksa babanın ailesine aittir. Geleneksel olarak aileler geniş aile biçiminde olup çok çocuklu aile yapısı hakimdir. Görüşülen kadınların en az beş çocuğa sahip olduğu ve kendi kardeş sayılarının daha fazla olduğu tespit edilmiştir. Zaten aile içinde çok çocuk olunca, geleneksel yapı içerisinde kadınların boşanmayı düşünemeyecekleri tahmin edilebilecektir (SK8, Suriye'de ve Türkiye'de Hayat, 2017) (SK9, 2017)(SK10, 2017) (SK1, Suriye'de ve Türkiye'de Hayat, 2017)(SK13, 2016).

Kadınların eğitimi meselesine gelecek olursak, genellikle çok yüksek olmadığını; nitekim kız çocukları için ailelerinin asıl hedefinin onları erken yaşta evlendirip aile kurmalarını sağlamak olduğu görülmektedir. Ama Suriye'de devlet tarafından eğitim konusuna da önem verilmektedir. Savaş öncesi 2008-2012 UNICEF verilerine göre hem kız hem de erkek çocukların okula kayıt ve devam oranı çok yüksek olup \%99 seviyelerindedir. Ortaokul seviyesine gelince bu oran hem kIzlar hem de erkekler için \%66'ya inmektedir (UNICEF, 2012). Ortaokul sırasında kızlar ve erkekler ayrı okullara gidip okul saati haricinde kızlar daha çok evde vakit geçirirken erkek çocuklar ev dışında boş zamanlarını değerlendirmektedir (SK7, Suriye'de ve Türkiye'de Hayat, 2017) (SK8, Suriye'de ve Türkiye'de Hayat, 2017). Şimdilerde kadınların evlilik yaşı ortalaması on altı olup iki yıl önce ve sonrası kaymalar olmaktadır. Genelde çocuklar ortaokuldan sonra okula devam etmemekte, kızlar için tercih evlendirme şeklinde gerçekleşirken, erkekler için çalışma hayatına girme şeklinde olmaktadır. Ne var ki son yirmi yılda Suriye'de de bazı değişiklikler olmaya başlamış, özellikle şehirlerde olmak üzere kadınlar erken evlenseler bile evli iken üniversite eğitimlerini devam ettirmişlerdir (SK8, Suriye'de ve Türkiye'de Hayat, 2017) (SK10, 2017) (SKOG4, 2017).

Geleneksel olarak hatta Medeni Kanun'a göre de erkekler aile reisi olduğu için ailenin geçimini erkekler sağlamak durumundadır. Bu yüzden kadınların ev dışında çalışmaları pek yaygın değildir. Eğer kadınlar çalışmak isterse babalarının ya da kocalarının izinlerini almak durumundadırlar. Bunun yanında kadınlar dışarıda çalışsa bile ancak kadınların yapabileceği düşünülen, doktorluk, öğretmenlik, avukatlık (özellikle aile hukuku), devlet dairelerinde sekreterlik görevlerinde çalışabilmektedirler (SK8, 2017) (SK1, Suriye'de ve Türkiye'de Hayat, 2017) (SE1, 2017) (SEOG1, 2017). Kadınların iş hayatına katılımı 2018 yılı istatistiklerine göre \%14,6'dır (The World Bank Group (US), 2019).

Suriye'de sosyal hayat çok önemli olup genelde aile hayatı çevresinde dönmekte ve dolayısı ile kadınların üzerinden yürümektedir. Aile denince genelde geniş aile akla gelmekte olup aileler kalabalıktır. Ailenin hemen bütün girdi çıktıları kadınlar tarafından düzenlenip belirlenmektedir. Mesela erkekler para kazanır ama onun büyük kısmını getirip eşlerine verirler ve ailenin geçim işini en 
azından mali olarak kadın düzenler. Belki dışarı gidip alış-veriş yapmaz ama paranın nelere harcanacağı kararını o verir (SEOG1, 2017).

İnsanlar genelde nesiller boyu aynı mahallede yaşadıkları için komşuları akraba, akrabaları komşudur. Komşular arasında kan bağı olmayan olsa bile onlarla da akraba benzeri ilişkiler kurulmaktadır. Hayat belirli bir rutin içinde devam etmektedir. Aile dışı, tiyatroya, sinemaya gitme vb. gibi faaliyetler yok denecek kadar azdır. Böylece hayat, evlilik, yeni doğan bebek ziyareti, cenaze merasimi ve diğer bazı büyük kutlamalar çevresinde dönmektedir (SK6, Suriye'de ve Türkiye'de Hayat, 2016) (SK2, Suriye'de ve Türkiye'de Hayat, 2017) (SK13, 2016).

Suriyeli kadınların günlük rutinlerinin en önemli kısımlarından bir diğeri de komşu ya da akraba kadınlarla kahve içmektir. Kadınlar hayatlarını yavaş, stressiz bir akış içinde geçirmektedirler. Sorumlulukları genelde yukarıda bahsettiğimiz alanlar ile sınırlıdır. Bu işler dışında nadiren başka sorumluluklar almaktadırlar, mesela ev için pazar, manav kısaca mutfak alışverişi bile yapmazlar. Bu tür alışverişler erkeklerin sorumluluğu altındadır. Suriye'de gelir çok az olsa bile, hemen herkesin kendi çapında kira ödemediği bir barınağı bulunmakta olup elektrik, su ve gaz oldukça düşük ücretlerle halka sunulmaktadır. O yüzden insanlar çok az para kazansa da kimseye muhtaç olmadan geçinebilmektedirler (SKOG1, 2017) (SK7, Suriye'de ve Türkiye'de Hayat, 2017) (SK12, 2016).

Sadece aile hayatı içinde dönüp durmak, aile fertlerinin birbirine karışmasına ve bunu kendilerine hak olarak görmelerine yol açmaktadır. Görüşme yapılan orta yaşı ıir öğretmenin hayatından bir kesit buna çarpıcı örnek teşkil etmektedir. Evliliğin ilk yıllarında ve tabii daha sonrasında, çocuklarının olmaması üzerine, kendi annesi ve kocasının aile fertlerinin nasıl olaya müdahale etmeye çalıştıklarını anlatmıştır. Her iki aileyi de sakinleştirmek için çiftin her iki tarafı kendi ailesine, kusurun kendinde olduğunu belirtmişlerdir. Aslında çiftin erkek üyesinin sıhhi problemi dolayısı ile çocukları olmamaktadır. Hayatı boyunca otuz iki çocuk doğuran annesi, kızının çocuğunun olmadığı hikâyesine hiç inanmamıştır. Kendi kızının da aynı şekilde doğurgan olduğuna inanmakta ve o yüzden kocasından ayrılıp başka bir erkekle evlenip çocuk sahibi olması konusunda baskı yapmaktadır. Aynı şekilde kocasının ailesi de ya boşanmaları gerektiğini ya da kocasının ikinci eş almasını teklif etmektedirler. Karı koca birbirlerini sevdikleri için bu baskılara mümkün olduğu kadar dayanmaya çalışmışlardır. Bu baskıları az çok idare etmişlerdir ki, onuncu yılda bir gün kocasının erkek kardeşi sanki eve baskın yapar gibi gelir ve bu işi bir şekilde çözmeleri gerektiğini yüksek perdeden belirtir. En iyi çözüm kocasının ikinci eş alması şeklindedir. Daha fazla dayanamayan kadın içeriden, kocasının kusurlu olduğunu belirten doktor raporunu alıp getirdiğinde büyük bir şok yaşanır. Kültürde genelde bu tür durumlarda kadın suçlu bulunduğu için hiç kimse kocanın kusurlu olabileceğini düşünmemiş ve yine kültür içinde bu duruma 
çözüm üretmeye çalışmışlardır (SKOG4, 2017). Ancak savaş ve göç Suriyeli kadınların sorumluluk alanlarını büyük oranda değiştirmiştir.

\section{Türkiye'de Hayat}

Suriyeli erkek ve kadınların hayatı Türkiye'de değişime uğramıştır ve bu değişim hâla devam etmektedir. Hayatlarının ne oranda değiştiği şimdilik tam olarak anlaşılamasa da kendileri bunun çok büyük boyutlarda olduğunu ifade etmektedirler. Mülakat yapılan bütün kadınlar, savaş öncesi Suriye'deki hayatlarının buraya göre çok daha mutlu olduğunu düşünmektedirler. Oradaki hayatlarının çok daha kolay olduğunu, zira burada birçok yeni sorumluluk yüklenmek zorunda olduklarını, bu yeni sorumluluklar nedeni ile sosyal hayatları için çok az zaman kaldığını ifade etmişlerdir (SK16, Suriye'de ve Türkiye'de Hayat, 2016)(SK13, 2016) (SK15, 2016) (SKOG1, 2017).

Bu sorumluluklar çerçevesinde günden güne erkek gibi olduklarını, çünkü çarşı, mutfak alışverişini artık kendilerinin yapmaya başladığını, faturaları ödediklerini, yardım kuruluşlarından yardım istemeye kendilerinin gittiğini ifade etmişlerdir (SK20, Suriye'de ve Türkiye'de Hayat, 2016). Sanki iki ateş arasında idiler: Bir yandan bu değişimden, omuzlarına yüklenen sorumluluktan, kendilerine ayıracak zaman azlığından nefret ederken, diğer taraftan Türk kadınlarının sahip oldukları haklardan olumlu anlamda etkilenmekten memnundular. Bütün bunlara rağmen kadınların ve dâhi erkeklerin çoğu, bu değişimin olumlu bir değişim olduğundan şüphe etmekteydiler (TKÖ1, 2017). Öyle ki genel olarak aile içinde herkes için roller değişmeye başlamıştır (SKOG1, 2017) (SKOG2, 2017).

Erkeklerin aile içindeki konumları belli belirsiz de olsa sarsılmaya başlamış ve büyük çoğunluğu ailesine Suriye'deki gibi bakamaz duruma gelmiştir. Bu yüzden kendilerini yavaş yavaş değersiz hissetmeye başlamışlardır. Hatta erkekliklerini kaybettiklerini hissetmektedirler. Bu durum hayattaki sosyal konumlanmalarını kaybetmelerine yol açmaktadır. O yüzden eskiye göre daha sinirli ve saldırgan olmaya başlamışlardır. Bu stressli yeni durum birçok erkek için, özellikle 40-50 yaş arası ölümle sonuçlanacak duruma kadar varmıştır. Araştırma yapılan bu beş yıl içinde o yaşlarda birçok erkeğin hastalık dolayısı ile ölüm olayına şahit olunmuştur (SK4, 2017) (SK19, 2017)(SKOG1, 2017) (SKOG2, 2017).

Bütün bu belirsizlik ve değişim içinde bile olsa, özellikle aile meselelerinde, kadınlar hâlâ olaya daha hâkim olup, aile üyelerini, hatta dünyanın birçok yerine dağılmış aile fertlerini, sosyal medya üzerinden olsa bile bir arada tutmaya çalışmaktadırlar (TKÖ2, 2017) (SEOG1, 2017)(SK10, 2017) (SKOG1, 2017). Bu durum, kadınların özellikle köklü değişim, karmaşa, kaos durumlarında zorluklarla başedebilme ve hayatta kalma bakımından daha güçlü oldukları yönünde bir çıkarsama yapmaya yönlendirmektedir. 
Suriye kültürüne göre erkekler ailenin özellikle maddi sorumluluğunu almak üzere yetiştirildiklerinden, Türkiye'ye geldikten sonra yardım kuruluşlarına gidip aileleri için bir şeyler istemek durumunda kalmak onlar için onur kırıcı bir durum olmuştur. Ama bunun yanında kadınlar, özellikle çocuklarını yokluktan korumak adına bu işi yapmakta bir mahsur görmemişlerdir. iş̧te bu işlev sırasında çoğu Suriyeli kadın yardım kuruluşlarında çalışan ya da kendileri sosyal medya üzerinden yardım faaliyeti başlatan birçok Türk kadınla tanışmak, iletişim içine geçmek durumunda kalmışlardır (SK12, 2016) (SK14, 2016) (SK20, Suriye'de ve Türkiye'de Hayat, 2016). Aynı kültürden gelindiği için özellikle aile mahremiyeti hassasiyetlerine dikkat eden yardım yapan Türk kadınlar, kapı kapı dolaşarak Suriyelilerin çoğunu istemeye fırsat vermeden kendileri yardım teklifinde bulunmuşlardır. Gündüz saatlerinde genelde erkekler iş arama peşinde olup evde olmadıklarından, kadınlar ve çocukların olduğu evlerde, kadın kadına karşılaşmak, konuşmak Suriyeli kadınları rahatlatan bir unsur olmuştur. Bu adım Suriyeli kadınları, yardım yapan Türk kadınlarla adım adım arkadaşlığa itmiş ve böylece bu çalışma Suriyeli kadınlara Türk toplumu ve sisteminin içine girebilmek için bir şans oluşturmuş̧tur (SK18, 2017) (SK13, 2016) (SK14, 2016) (Topcu, The Changing Situation of Syrian Women in the Family and the Society Through the Solidarity Between Turkish and Syrian Women, 2017).

Ilk başlarda Ankara'da Nezahat Albay önderliğinde kadınların kendi girişimleri ile başlattığı Türkçe kurslarına başladıktan sonra, Suriyeli kadınlar için diğer fırsatlar da yavaş yavaş oluşmaya başlamıştır. Böylece daha fazla insani yardım almaya, sağlık, eğitim, konularında daha fazla danışmanlık hizmetleri almaya başlamış ve yaşadıkları çevre ve konutlarda da iyileşmeler başlamıştır (Topcu, E. Kurtulmuş, S., 2017).

Türkçe kursları, Suriyeli kadınlara sadece kendilerini Türk toplumuna açma bakımından imkân sağlamamış, aynı zamanda kursa gelen diğer Suriyeli kadınlarla da sosyalleşme imkânı sunmuştur. Böylece ortak faaliyetler düzenleyip kendi kendilerini güçlendirme imkânları oluşmuştur (SK15, 2016) (SK17, Suriye'de ve Türkiye'de Hayat, 2017). Bu kadınlardan bazıları önceleri Türk kadınlarla beraber yardım faaliyetleri yaparken, zamanla yine onların yardımı ile kendi sivil toplum kuruluşlarını oluşturmaya başlamışlardır. Böylece yeni geldikleri toplumdaki kurban konumlarından girişimci (agent) konumuna adım atmaya başlamışlardır (SK21, 2017)(SKOG1, 2017) (SKOG2, 2017).

Gaziantep'e 2012 yılında beş çocuğu ve kocası ile gelen Maryam, 2017 yılında diğer Suriyeli ve Türk aktivist kadınlarla, başkanlığını kendi yaptığı bir sivil toplum kuruluşu oluşturmayı başaran kadınlardan biridir. Savaş öncesi Suriye'de refah içinde bir hayat süren, Maryam kocası gibi kendisi de eczacıdır. Her ikisinin ayrı eczaneleri olup ayrıca Suriye'de iken ilaç fabrikası kurma çalışmaları içindedirler. Büyük bir evde yaşayan aile, yanlarında ev işleri ve eczanedeki işler için birçok işçi çalıştırmaktadırlar (SKOG1, 2017). 
Bütün bu imkânlara rağmen Maryam Suriye'de iken kendini çok zayıf, güçsüz hissetmektedir. Genelde gündelik hayat pratiklerini oluşturan yemek pişirme, ev temizliği, dışarı çıktığında gideceği yerlere götürme gibi her türlü işlerini yanında çalışan işçiler sayesinde yürütmektedir. Kendisi aslında aktif olarak fazla bir sorumluluğa sahip değildir. Ama yine de kendini çok yorgun ve güçsüz hissedip sürekli uyuma ihtiyacı hissetmektedir. Savaş başlayıp hayatta kalabilmek için Türkiye'ye sığındıklarında kelimenin tam anlamı ile her şeye sıfırdan başlamak durumunda kalmışlardır. Karı-koca her ikisi de iş aramış ama bir türlü bulamamışlardır. Bunun üzerine ergenlik çağında olan çocukları okula gitmek yerine bütün aileyi geçindirmek için çırak olarak çalışmaya başlamışlardır. İki yıl ergenlik çağındaki çocuklarının kazandığı ile geçinmek zorunda olan anne ve baba, Maryam'ın devam ettiği bir kadın kuruluşu vasıtası ile Suriyeli çocuklar için öğretmenlik yapma imkânı bulması ile en büyük oğulları öğrenimine kaldığı yerden devam edebilme fırsatını yeniden elde etmiştir. Bu durum hayatlarında önemli bir dönüm noktası olmuştur. Anne ve baba tekrar çalışmaya, çocuklar rahatlıkla okula gitmeye başlamışlardır. Bu arada Maryam'ın hayata bakışı da tamamen değişmiştir. Eskiye gore çok daha girişimci, yeni adımlar atan, içindeki saklı yetenekleri ortaya çıkaran bir kadın ortaya çıkmıştır. Böyelce, Maryam gerçek bir aktivist olmuştur (SKOG1, 2017).

Aynı şekilde başarısız, eziyet gördükleri evliliklerini yürütmek zorunda kalan birçok Suriyeli kadın da cesur adımlar atarak Türkiye'de yeni hayatlar kurmaya başlamışlardır. Bu adımlar sayesinde hem çocuklarını hem kendilerini kurtarmış ve gelecek için umut beslemeye başlamışlardır. Aynı tür evliliği, Suriye'de, genelde ekonomik olarak bağımsız bir hayatları olmadığı, boşanmış kadının toplumda iyi gözle görülmemesi nedenleri ile bitirmeye cesaret edemeyen kadınlar, Türkiye'de kendilerine sunulan çeşitli meslek edindirme eğitimleri, sosyal yardım imkânları ve kendilerinin de bazı sosyal yardım faaliyetlerine katılma şansı sayesinde kendilerine çevre edinip iş bulma fırsatları dolayısı ile hayatlarında radikal adımlar atmaya başlamışlardır (SK5, Suriye'de ve Türkiye'de Hayat, 2017)(SK10, 2017) (SKOG1, 2017). Özellikle boşanmış, çocuklarına kendi bakan Suriyeli kadınlar, savaş bittiğinde geri dönmek ister misiniz sorusunu, gitmek istemedikleri yönünde cevaplamışlardır. Türkiye'de kendilerini hukuki olarak çok daha korunaklı hisstemekte ve Suriye'de olmayan ama burada çeşitli alternatiflerle kendilerini geliştirmek için önlerine çıkan ya da çıkabilecek olan fırsatların farkında olduklarını belirtmektedirler. Erkeklerin savaşta ölmüş olmasından dolayı Suriyeli kadınlar arasında dul olanların oranı hayli fazladır. Mesela SODEM'de Türkçe kursuna gelen Suriyelilerin yirmi kişilik sınıfında genelde dört-beş kadın dul olup yaşları 25-35 arasıdır (TEÖ1, 2017) (SK7, Suriye'de ve Türkiye'de Hayat, 2017)(SK10, 2017) (SK15, 2016) (SK17, Suriye'de ve Türkiye'de Hayat, 2017).

Suriye'de toplumsal olarak en düşük seviyede bulunanlar için Türkiye yeni bir fırsat olmuştur. Üst ya da orta gelir grubundan gelen Suriyeliler, oradaki hayatlarına göre burada nisbi olarak daha düşük seviyede bir hayat sürerken, işçi 
sınıfından olan Suriyeliler, Türkiye'de daha iyi iş bulma ve ailelerinin bütün fertlerinin çalışma imkânlarından dolayı daha iyi bir gelir düzeyi elde etmişlerdir. Aileler kalabalık bir şekilde bir arada yaşadıkları ve aile fertlerinin, özellikle erkeklerin çoğu çalıştığı ve ortak bir bütçe ile aileyi geçindirdikleri için bu durum hayat seviyelerini Suriye'dekine göre yükseltmiştir (SKOG1, 2017) (SKOG2, 2017).

Hatta bu kesimden gelen kadınlar bile, Suriye'de sosyal baskılar sebebi ile aileleri için para kazanma imkânına sahip değilken, şimdi gerek ev içinde, gerek dışarda çalışma fırsatları yakalamaktadırlar. Özellikle Gaziantep'te, daha az oranda olsa da Ankara'da da evden yapılabilecek parça başı işlerle geleneksel yapılarını da fazla yıpratmadan kadınlar evden para kazanmaya başlamışlardır (SK8, Suriye'de ve Türkiye'de Hayat, 2017) (SK16, Suriye'de ve Türkiye'de Hayat, 2016)(SKOG1, 2017). Ama çalışmak, aileleri için para kazanmak alışkın oldukları bir durum olmadığından şimdilik bu konuda çok zorlanmaktadırlar. Birçok kadın kocaları öldüğü ya da Suriye'de kaldığı için, burada çocukları ile yalnız başına mücadele vermek zorunda kalmaktadırlar. Bir yandan bu durum zorlarına gitse de, diğer yandan hayatla başetmeyi öğrenip güçlenmektedirler. Suriye'de kalan bazı kocalar hâlâ Türkiye'deki karılarından geleneksel beklentiler içinde olsalar bile, kadın bütün bu yaşanmışlıklar ile değişmekte ve bu durum sancılı bir dönüşüm getirmektedir (TKÖ1, 2017).

Yukarıda bahsettiğimiz Maryam kurduğu sivil toplum kuruluşu vasıtası ile bu konuda önemli bir rol oynamakta ve Suriyeli ailelerden yardıma ihtiyacı olanları kendi aralarında kurdukları ağ ile tespit edip onlara nelere ihtiyaçları varsa o konuda yardım sağlayarak daha iyi bir duruma gelmelerinde yardımcı olmaktadır. Böylece diğer Suriyeli kadınlar için bir rol model olup onlarda, biz de yapabiliriz düşüncesinin uyanmasına sebep olmaktadır (SKOG1, 2017) (SKOG2, 2017).

Savaş en çok kadınları ve çocukları vuran acımasız bir olgudur. Savaş ortamında bulunma, kaçış, yeni gelinen ülkede, bütün bu evrelerde kadın için çok daha özel zorluklar vardır. Savaş bölgesinde ve kaçış anında tecavüze, tacize uğrama, özel kadınlık durumları (aylıkhaller, hamilelik vb.) dolayısı ile kadınlar çok daha fazla zorluklar çekmektedirler. Kaçarken ya da gelinen ülkede kalınan yerlerin hijyenik koşulları, kadın-erkek hassasiyetine dikkat edilmemesi gibi unsurların hepsi en çok kadınları etkilemektedir (TKÖ1, 2017). Mesela, Suriyeliler geldiklerinde buldukları ilk kiralık eve şartları ne olursa olsun yerleşmişler ve birkaç aile (bazen 40-50 kişi) bir arada yaşamışlardır. Bu durum sağlık ve hijyen koşullarının gerektiği gibi yerine getirilmesini engellemiş, bir çok kadın ve kız çocuğu saçları uzun olup yıkamak için yeterli su bulamadıkları için bitlenmişler daha da acısı küçük kız çocukları aile içi tacize bile uğramışlardır (SKOG1, 2017) (SKOG1, 2017).

Genelde bütün Suriyeliler, özelde Suriyeli kadınlar hayatın birçok aşamasında ayrımcılıklara uğramaktadırlar. Kadınlar hastanelerde kötü davranışlara maruz kalmakta, kendi başlarına randevu alamamaktadırlar. Kadınlık 
ile ilgili hastalıklarında ya da hamile olduklarında hastanelerdeki onlara karşı olan davranışlar bazan hakarete kadar ilerlemektedir. Ayrıca ev bulma, iş bulma konusunda çok zorluklar yaşamaktadırlar. İşe girseler bile işyerinde ayrımcılığa uğramaktadırlar. Kadınlar okullarda çocuklarının da ayrımcılığa uğradıklarını ama dil bilmedikleri için bunu ifade edemediklerini belirtmektedirler. Savaş dolayısı ile yaşadıkları travmalar ve şimdi Türkiye'de uğradıkları ayrımcılıklar kadınların depresyon yaşamasına yol açmaktadır (D1, 2017)(SKOG1, 2017) (SKOG2, 2017) (TEÖ1, 2017)(TKÖ1, 2017).

\section{Anahtar Bulgular}

Bilindiği gibi savaştan en çok zarar görenler kadınlar ve çocuklardır. Bu durum onlarda büyük travmalara yol açmaktadır. Genellikle travma sonrası insanlar o konu hakkında kendilerini konuşmaya hazır hissetmeyebilirler. Araştırma çerçevesinde görüştüğümüz kadınların çoğu da savaş esnasında yaşadıkları trajik olaylar hakkında konuşmaya pek istekli olmamışlardır. Savaşı yaşayan bu insanlar onun etkilerinden bir an önce kurtulmak isterken, geldikleri ülkelerde onlara yardım eden kişi ve gruplar ise onları yardıma muhtaç insanlar olarak değerlendirip kurban olarak görme eğiliminde olabilmektedir. Savaş mağdurları ise yeni geldikleri bu ülkede daha önceki hayatlarına benzer bir hayat sürdürme isteğindedirler. Yani sürekli savaş konuşmak değil hayatlarını yeniden kurup huzur içinde devam ettirmek arzusundadırlar. Eski hayatlarına benzer bir hayat kurmaya çalışırken, tanımadıkları yeni bir toplumda, yeni kültürel normlar ve dil ile baş edebilmek için özel gayret sarf etmeleri gereklidir (SKOG2, 2017).

Suriyeli kadınlar için Türkiye'deki hayat onlara bazı ek sorumluluklar getirmesi dolayısı ile oldukça farklıdır. Kadınlar, alış-veriş yapma, faturaları ödeme, aile için para kazanma, aile için ev dışında ek yükümlülükler alma gibi sorumluluklar dolayısı ile kendilerinin burada erkek gibi olduklarını belirtmektedirler. Bu durum onların tarihi olarak alışa geldikleri toplumsal cinsiyet rollerini değişime uğratmaktadır. Diğer taraftan Suriyeli erkeklerin geleneksel rollerinde, Suriye'deki gibi, ailenin bütün iaşesini karşılama eylemini yerine getiremedikleri için ailevi ve toplumsal rollerinde bazı sarsılmalar olmaktadır. Bu durum Suriyeliler arasında aile ve toplum içinde toplumsal cinsiyet rollerinin değişmeye başladığının bir göstergesidir.

Bir diğer önemli konu, Suriyeli kadın ve çocuklara yardım etmek için Türk kadınların başlattıkları yardım faaliyetleri ile Suriyeli ve Türk kadınlar arasındaki dayanışma çerçevesinde gelişen arkadaşık ilişkileri Suriyeli kadınların bu ilişkilerden aldıkları cesaretle, içinde bulundukları toplumda daha aktif hâle gelmeleri, hatta bazılarının kendi sivil toplum kuruluşlarını kurma girişimleridir.

Bazı Suriyeli kadınların sosyal girişimci olması, onların, daha büyük kitle olan kurban durumundaki diğer Suriyeli kadın ve çocuklara ulaşımlarını 
kolaylaştırmaktadır. Böylece onların içinde bulundukları zorlukları aşmalarında yardımcı olup ayrıca Türkiye'de eğitim, sağlık, sosyal ve iş hayatı hakkında bilgilendirmelerde bulunmaktadırlar. Ayrıca kadınlara meslek eğitimi imkânları ve çocuklarına okullarında daha başarılı olmaları için ek kurslar düzenlemektedirler. Bütün bu çalışmalar nihai olarak iki toplumun daha uyumlu bir şekilde yaşamasına yardımcı olmaktadır.

Bir diğer tespit ise, kadınların özellikle savaş gibi aşırı karmaşık durumlarda bile, ailelerini korumak adına her türlü fedakârlığı yapıp kriz anında daha akılcı kararlar alabildikleri yönündedir. Suriyeliler şu an bütün dünyaya dağılmış olup kadınlar aile fertlerini sosyal medya üzerinden bir arada tutmaya çalışmaktadırlar. Bu durum, kadınların özellikle köklü değişim, karmaşa, kaos durumlarında zorluklarla baş edebilme ve hayatta kalma bakımından daha güçlü oldukları yönünde bir çıkarım yapmaya yönlendirmektedir.

\section{Tartışma}

$\mathrm{Bu}$ bölümde bulgular, teorik çerçeve doğrultusunda ele alınacağından dolayı, teorik çerçeve ile ilgili kısa, özet halinde tekrar bir ön bilgilendirme yapılması uygun görülmüştür. Kapasite Yaklaşımı tam anlamı ile tanımlanmış bir teori olmaktan çok bir düşünce çerçevesi, normatif bir araçtır ve bütün normatif sorulara cevap vermez. Sadece kişilerin bulundukları ortamlarda, kendileri o ortamın imkânı ile neler başarmışlar, daha başka imkânlar sağlanan bir ortam olsaydı neler başarabilirlerdi sorusuna cevap arayan bir yaklaşım olup bu çerçevede insanların şartlarının en iyi hangi şekilde değiştirilmesi gerektiğinin cevabını arar. Bu düşünceyi ilk olarak Amartya Sen ortaya atmış daha sonra Martha Nussbaum, kapasite gelişimi için evrensel geçerli olduğunu düşündüğü bazı kriterler geliştirmiştir. Oysa Amartya Sen bu kriterleri çok keskin bir şekilde önceden belirleme eğiliminde değildir ve ortamdaki kişilerin ortak kararı ile belirlenmesi taraftarıdır. Her iki düşünürün de “Kapasite Yaklaşımı”nda ana çıkış noktaları, insan gelişiminin sadece gelir düzeyi ile oluşan fakirliğe odaklanılmaması üzerinedir. Amartya Sen yaklaşımı açılamak için iki temel unsur olduğunu belirtmektedir. Birisi işlevsellik, diğeri de kapasitedir. İşlevsellik kişilerin hayatlarında şimdiye kadar kazandıkları, geliştirdikleri imkan ve yetenekleri olarak belirtilirken, kapasite şimdiye kadar elde edilmiş durumları daha da geliştirmek için ne gibi yeni imkanların sunulması ile ilgilidir. Sen, kapasite gelişiminde herkes için standart, belirli bir çerçeve çizmek yerine, kişilerin kapasiteleri kendilerinin belirlemeleri ve de sunulan imkânlar içinden istedikleri kapasite imkânlarını kendilerinin özgürce seçmeleri üzerinde durmaktadır. Çünkü her ortam, kültür, tarihi süreç ve o ortamlardaki insanların önem verdiği hayat şekilleri farklıdır (Saigaran, Karupiah, Gopal, 2015). 
Bütün bu bulguların eşliğinde Suriyeli kadınların hayatlarına baktığımızda onların aile merkezli yetiştirildikleri ve bu durumun hayatlarında önemli bir unsur olduğu görülmektedir. Bu sadece öğrenilmiş bir mesele olmayıp aynı zamanda bilinçli olarak seçip değer verdikleri (reason to value) bir durumdur. Suriyeli kadınların hemen hepsi, bundan sonrası için de, aile içinde kalıp, hayat ile ilgili diğer bütün unsurları aile çerçevesinde döndürmek istemektedirler. Kariyer yapmak ilk hedefleri arasında değildir. Amartya Sen Kapasite Yaklaşımı dâhilinde insanların hayatta gerekçeli olarak değer verdikleri seçimlerinin önemi üzerinde durmaktadır. Daha önce de bahsedildiği gibi “Kapasite Yaklaşımı”nın iki aşamasıişlevsellik ve kapasite (imkânları olsaydı neleri seçerlerdi) vardır ve Suriyeli kadınlar için işlevsellik basamağında sahip oldukları en önemli unsur olarak aile ortaya çıkarken, kapasite olarak da, bundan sonraki hayatlarını aile içinde devam ettirmek istedikleri tespit edilmektedir.

Dünyanın her yanına dağıldıkları bu kaotik durumda, ailenin en önemli devam ettirici unsuru, kadın olarak ortaya çıkmaktadır. Kadınlar sosyal medya üzerinden bile olsa ailelerini devam ettirmek için bütün gayretlerini göstermekte ve buna çok değer vermektedirler. Sen, bu noktada hayat seviyesinin ölçümü için sadece fayda, gelir ve kaynaklar açısından bakan yaklaşımları eleştirmektedir. Onun için kişilerin kendi gerekçelendirmeleri ile seçtikleri değerler en önemli unsur olarak değerlendirilmelidir. Faydacı yaklaşım çerçevesinde bir kişinin hayatının iyi bir şekilde devam etmesi için onun temel bazı ihtiyaçlarının karşılanmış olması gereklidir. Sen, bu faydacı yaklaşıma karşı çıkmakta, bir taraftan, temel ihtiyaçların belirlenmesinde kimin söz sahibi olacağı konsunu tartışırken, diğer taraftan hayatta başka hiçbir alternatif tanımamış bir insanın elinde olan imkânlardan çok mutlu olabileceğini o yüzden kişilerin hayattan memnuniyetlerinin izafi olduğunu belirtmektedir. Bu bakımdan Suriyeli kadınların aile kurumunu her ne şartta olursa olsun devam ettirmek için verdikleri mücadele saygı ile karşılanmalıdır. Bu durumda kapasite geliştirme unsuru olarak aile kurumunu güçlendirerek bütün aileyi göz önünde bulunduracak imkanlar sunulması gerektiği ortaya çıkmaktadır.

Suriyeli kadınların önem verdiği diğer bir durum ise yaşayış şekilleri ve dini tercihleridir. Türkiye'de kalan, hatta tercih hakkı olduğu halde Batı ülkelerine gitmeyen birçok Suriyeli kadın, kalmak için en önemli sebep olarak dini tercihlerini (reason to value) göstermektedirler. Eğer imkânları olsaydı başka bir ülkeye gitmek isterler miydi sorusunu, Türkiye'de kalmak istedikleri, çünkü burada ezan sesi duydukları, kıyafetleri bakımından çok dikkat çekmedikleri, çocuklarını burada istedikleri gibi yetiştirebilecekleri o yüzden gitmeyi düşünmedikleri şeklinde cevaplamışlardır.

Suriyeli kadınların bir başka değer verdikleri durum da Türkiye'deki özgür ve güvenli ortamdır. Eğer barış sağlanırsa Suriye’ye geri dönmek isteyip istemediklerini sorduğumuzda, hayatta kendisi ve çocukları için yalnız mücadele etmek zorunda olan kadınlar ve özellikle genç kadınlar, geri dönmek 
istemedikleri yönünde beyanda bulunmuşlardır. Türkiye'de kadın olarak haklarının daha korunmuş olduğunu ve toplumsal olarak daha güvende olduklarını belirtmektedirler.

Türkiye’yi toplumsal ve hukuki olarak güvenli bir ortam olarak görmenin yanında, kendilerini geliştirebilmek için fırsatlar olan bir ülke olarak da görmektedirler. Suriye'de iken maddi imkânları çok daha fazla olduğu, evde ve kendi işyerinde yardımcıları, istediği an tatil yapabilecek maddi imkânları olduğu halde orada kendilerini işe yaramaz ve dolayısı ile güçsüz hissettiklerini, oysa Türkiye'de, özellikle bir kadın olarak toplumsal faaliyet bakımından aktif katılım sağladıklarını bunun onlara kendilerini iyi hissettirdiğini ifade etmektedirler.

İşlevsellik bakımından, özellikle araştırma alanı içinde olan kadınların genelde evli oldukları, bunun onlara Suriye'de belirli bir güvence sağladığı, evli olmasa bile aile tarafından sarılıp sarmalandıkları, bu çerçevede devletin de sağladığı imkânlarla çok az para ile de olsa kimseye muhtaç olmadıkları bir hayat yaşadıkları görülmektedir. Amartya Sen'in en temel kapasite unsurları olarak belirttiği, başının üstünde bir dam olması, sağlıklı olması, yiyecek ekmeğinin olması, hayatta olması gibi unsurların sağlandığı tespit edilmektedir. Ama Amartya Sen kapasite yaklaşımına en çok özgürlük boyutundan bakmakta ve bunun hiç gözden kaçırılmaması gerektiğini belirtmektedir. Bu noktada işte işlevsellik bakımından Suriye'deki hayat açısından en büyük açık olarak özgürlük ortaya çıkmaktadır. Çünkü kadınlar için de, erkekler için de hayat aile ortamı dışında pek gerçekleşememektedir. Eğer birkaç aile bir araya gelip üç-dört araba ortak tatile çıksalar bile tatilden döndüklerinde sabah saat dörtte muhaberat elemanlarının kapıya dayanması ile uyanıp karakolda hesap vermek durumunda kalmaktadırlar (SK22, Suriye'de ve Türkiye'de Hayat, 2018). Yani Suriye'de iken hayatlarını özgür bir şekilde şekillendirme imkânları bulunmamaktadır.

Suriye'de de kadın dernekleri vardır ama bu dernekler rejim tarafından kurulmuş ve rejimin ideolijisini gerçekleştirmek için faaliyet gösteren derneklerdir. Bunun dışında herhangi bir dernek kurulmasına izin verilmemektedir (SK22, Suriye'de ve Türkiye'de Hayat, 2018). Bu yüzden birçok kadın için Suriye'de işlevsel olarak faaliyet gösterebilecekleri ya da faaliyetlerine katılabilecekleri kadın dernekleri olduğu halde bu dernekler özgür seçim çerçevesinde hareket eden kurumlar olmadığı için işlevsel olarak pek işe yaramamakta, dolayısı ile kapasite geliştirimi bakımından herhangi bir rol oynamamaktadır.

Suriye'de devlet dairelerinde ișe girebilmek ya da askeriyede görev almak sadece belirli bir gruba tanınmış (Nusayrilerin üst kesimindekiler) imkânlar olup oraya alınmasını istedikleri kişileri seçmek üzere ustaca düzenlenmiş bazı mekanizmalar bulunmaktadır. Mesela üniversiteye gitmek isteyen ya da devlet dairesine ya da askeriyede görev almak isteyen kişiler, devletin düzenlediği bazı kamplara katılmak zorundadır. Bu kamplar kadın erkek karışık kamplardır ve Suriye'deki özellikle Sünni Müslümanların hayat şekillerine pek uymamaktadır. Bu 
durumda Sünni Müslümanlar çocuklarını, özellikle kızlarını bu kamplara göndermemekte ve sistemden otomatik olarak dışlanmaktadırlar (SK22, Suriye'de ve Türkiye'de Hayat, 2018).

Ayrıca aileler de kendi içlerinde seçim mekanizmalarını işletmekte mesela kızlarını bulundukları şehir dışında başka şehirlere üniversite okumak için göndermemektedirler. Özellikle kız evlatlar bulundukları şehirde hangi fakülteler varsa o tercihleri yapmak durumunda kalmaktadırlar. Bunun yanında, toplumun kadınlara okuyup meslek sahibi olsalar bile biçtiği bazı mesleki roller olduğu için bilinçaltının harekete geçmesi ile kadınlar kendilerini farkında olmadan bu mesleki eğitim içinde bulmaktadırlar.

Kapasite bakımından Türkiye'de büyük imkânlar yakalamışlardır. Mesleklerini çok daha özgür bir şekilde icra edebilirler ama önce diplomalarını getirmiş olmaları, sonra denklik yaptırmaları, daha sonra özellikle bazı meslekler için zorlu bir sınavı başarmaları ve en önemlisi çok iyi derecede Türkçe konuşmaları gerekmektedir. Bir kapasite geliştirme imkânı olarak Türkçe kursları gerek sivil toplum kuruluşları gerek belediye kuruluşları gerekse üniversiteler tarafından sunulmaktadır ama yine de tam olarak Türkçe öğrenme işlevi gerçekleşememektedir. Bunda Suriyelilerin kendi dillerini unutma korkusu olduğu gibi Türkiye'de dil öğretme konusunda bir problemin olduğu gerçeği de vardır.

Yine kapasite geliştirilmesinde en önemli unsurlardan biri Türk kadınların Suriyeli kadınlarla yardım faaliyetleri çerçevesinden iletişim kurup sonra bu iletişimi devam ettirmeleri ve onları Türkiye'deki sosyal hayata çekmeleri olmuştur. Sosyal ağlar en önemli kapasite unsurlarıdır. Sosyal ilişkiler Suriyeli kadınların özellikle kendilerine güvenlerinin ortaya çıkması bakımından önemli bir araç olmuştur.

\section{Sonuç}

Kadınlar için Suriye'deki hayat ile Türkiye'deki hayat önemli farklılıklar arz etmektedir. Suriye'de daha geleneksel, rollerin çok önceden belli olduğu bu yüzden kız ve erkek çocuklarının o rollere göre yetiştirildikleri bir sosyal sistem vardır. Bu sosyal sistemde fazla giriş çıkışlar, iniş çıkışlar bulunmamakta, insanlar yarım asır aynı mahalle komşuları ile bir arada yaşamaktadırlar. Bu yüzden kendileri fark etmese bile sosyal denetim çok güçlü bir şekilde işlemektedir. Bu güçlü sosyal denetim, devletin gizli haber alma örgütü Muhaberat'ın kontrolü ile hayatı daha kısıtlı bir alana sıkıştırmaktadır. Hayat yıllarca aynı rutin üzere devam etmektedir.

Türkiye'ye geldikten sonra insanların maddi durumları, aile yapıları, aile yaşantıları, kültürel çevreleri, konuştukları dil değişmek durumunda kalmıştır. Kadınlık ve erkeklik rolleri de değişime uğramış, erkekler Suriye'deki gibi 
kendilerinden beklenen aile reisliği rollerini yerine getirememeye başlamışlardır. Bu durum onların onurlarını zedelemiş ailelerine yardım istemek için bile olsa yardım kuruluşlarına gitmekte zorlanmışlardır. Suriye'de daha çok aile içinde bir hayat sürdüren kadınlar Türkiye'de kamusal alana açılmaya başlamak zorunda kalmış, ailelerine yardım bulmak için yardım derneklerine gitmiş, toplu taşımları kullanmış, dil kurslarına gitmiş, daha önce tanımadıkları Suriyeli ve Türk kadınlarla sosyalleşmiş böylece başka bir kültür ve dile yakınlaşmaya başlamışlarıdır. Aynı zamanda yavaş yavaş çalışma hayatına da adım atmaya, Suriye'de cesaret edemedikleri sürdüremedikleri evliliklerini bitirme, boşanmaya daha cesur yaklaşmaya başlamışlardır. Bunda Türkiye'deki kadınlara sağlanmış olan haklar önemli rol oynamaktadır. Ama bu durum şimdilik birçok Suriyeli kadın ve erkek tarafından aile yapılarına bir tehdit olarak algılanmaktadır.

Yukarıdaki tartışma çerçevesinde, Suriyeli kadınların şimdiye kadar hayatta gerçekleştirdiği unsurlar (işlevsellik); aile, eğitim, hayata pozitif bakış, dini değerler ile şekillenmiş bir hayat tarzı ve insani ilişkiler olarak sıralanabilir. Türkiye'ye geldiklerinde onlara yepyeni bir ortam ve yeni imkânlar sunulmuştur. Kadın hakları bakımından kanunlarla garanti altına alınmış bir sosyal ortam vardır. Bu sosyal ortam onlara aynı zamanda kendilerini geliştirmek ve gerçekleştirmek için yeni fırsatlar sunmaktadır. Ancak bu yeni fırsatlar onlara altın tepside sunulmamakta, dil sorunu, diplomalarının denkliği, yeni sosyal ağlara ulaşım, Türkiye'deki toplumsal yapı ve sistemin nasıl işlediğini bilmemek şeklinde engeller bulunmaktadır. Bundan sonrası için, geldikleri bu yeni yerdeki kapasite imkanlarını nasıl kullandıkları, onu kendi yararlarına olacak şekilde nasıl dönüştürdükleri ve dönüştürebilecekleri konuları çok iyi bir şekilde değerlendirilip, onlara sunulan imkânların nasıl geliştirilebileceği üzerinde durulması gereklidir.

\section{Kaynakça}

Akdemir, S. (2000). Suriye"deki etnik ve dini yapının siyasi yapının oluşmasındaki rolü. Avrasya Dosyası Arap Dünyası Özel, 6(1), s. 201-237.

Boyd, M. (1975, 11). The status of immigrant women in Canada. Canaidian Review of Sociology, s. 406-416.

D1. (2017, 5 26). Değerlendirme Toplantısı. (E. Topcu, Röportaj Yapan)

D3, \& Toplantısı, 3. D. (2017, 5 5). Genel Değerlendirme. (E. Topcu, Röportaj Yapan)

Divorce Statistics, Syria 2002. (2002). Divorce Statistics, Syria 2002: https://knoema.com/jglrmtd/divorce-statistics?tsld=1001210 adresinden alındı

Dwyer, S. C. \& Buckle, J. L. (2009). The Space Between: On Being an InsiderOutsider in Qualitative Research. International Journal of Qualitative Methods, s. 54-63.

Eijk, E. v. (2014). Pluralistic Family Law in Syria: Blane or Blessing? . (Editor-in-Chief Prof. Dr. Andrea Büchler, University of Zurich, Switzerland), EJIMEL, Electronic Journal of Islamic and Middle Eastern Law, Vol. 2, s. 73-82. 
Fincher, R., Foster, L., \& Wilmot, R. (1994). Gender Equity and Australian Immigration Policy. Sydney: Australian Government Publishing Service.

Kanunu, G. K. (2013, 4 4). Yabancılar ve Uluslararası Koruma Kanunu . Yabancılar ve Uluslararası Koruma Kanunu 6458. Ankara, Türkiye: Resmi Gazete.

Kuklys, W. (2005). Amartya Sen's Capability Approach Theoretical Insights and Empirical Applications. Berlin: Springer-Verlag.

Ministry of Interior, Syrian Arab Republic. (2019). Ministry of Interior, Syrian Arab Republic,:

http://www.syriamoi.gov.sy/portal/site/arabic/index.php?node=55333\&cat $=1$ $831 \&$ adresinden alındı

Moroksavic, M. (1984). Women in Migration. International Migration Review, Winter 18:882-1382.

Naples, N. (1996). A feminist revisiting of the insider/outsider debate: The 231 Enquire 2(2) 'outsider phenomenon' in rural lowa. Qualitative Sociology, Vol. 19, No. 1, s. 83-106.

Nussbaum, M. (2000). Women and Human Development The Capabilities Approach . Cambridge: Cambridge University Press .

Phoenix, A. (200). Practising feminist research: The intersection of gender and 'race' in the research process. Bhavnani içinde, Oxford Readings in Feminism and 'Race' (s. 203-219). Oxford: Oxford University Press.

Qanoon Ahwaal Shakhsiyyeh, Book 1: Marriage. (2019, 6 10). Qanoon Ahwaal Shakhsiyyeh:

online.com/\%D9\%82\%D8\%A7\%D9\%86\%D9\%88\%D9\%86https://www.qanoon\%D8\%A7\%D9\%84\%D8\%A3\%D8\%AD\%D9\%88\%D8\%A7\%D9\%84\%D8\%A7\%D9\%84\%D8\%B4\%D8\%AE\%D8\%B5\%D9\%8A\%D8\%A9\%D8\%A7\%D9\%84\%D8\%B3\%D9\%88\%D8\%B1\%D9\%8A-doc/ adresinden alındı

Qanoon, A. S. (2019). Qanoon Ahwaal Shakhsiyyeh. Qanoon Ahwaal Shakhsiyyeh, Book 2: Divorce: https://www.qanoononline.com/\%D9\%82\%D8\%A7\%D9\%86\%D9\%88\%D9\%86\%D8\%A7\%D9\%84\%D8\%A3\%D8\%AD\%D9\%88\%D8\%A7\%D9\%84\%D8\%A7\%D9\%84\%D8\%B4\%D8\%AE\%D8\%B5\%D9\%8A\%D8\%A9\%D8\%A7\%D9\%84\%D8\%B3\%D9\%88\%D8\%B1\%D9\%8A-doc/ adresinden alındı

Qanoon, A. S. (2019). Qanoon Ahwaal Shakhsiyyeh. Qanoon Ahwaal Shakhsiyyeh Book 2: Divorce: https://www.qanoononline.com/\%D9\%82\%D8\%A7\%D9\%86\%D9\%88\%D9\%86\%D8\%A7\%D9\%84\%D8\%A3\%D8\%AD\%D9\%88\%D8\%A7\%D9\%84\%D8\%A7\%D9\%84\%D8\%B4\%D8\%AE\%D8\%B5\%D9\%8A\%D8\%A9\%D8\%A7\%D9\%84\%D8\%B3\%D9\%88\%D8\%B1\%D9\%8A-doc/ adresinden alındı Qanoon, Al-Bitaqah Ash-Shakhsiyyeh Aj-Jadeed Madde 1. (2003). Qanoon AlBitaqah Ash-Shakhsiyyeh Aj-Jadeed: https://www.mohamah.net/law/\%D9\%86\%D8\%B5\%D9\%88\%D8\%B5-\%D9\%88\%D9\%85\%D9\%88\%D8\%A7\%D8\%AF-\%D9\%82\%D8\%A7\%D9\%86\%D9\%88\%D9\%86\%D8\%A7\%D9\%84\%D8\%A8\%D8\%B7\%D8\%A7\%D9\%82\%D8\%A9- 
\%D8\%A7\%D9\%84\%D8\%B4\%D8\%AE\%D8\%B5\%D9\%8A\%D8\%A9-\%D8 adresinden alındı

Refworld.

(2019).

Refworld

UNHCR:

https://www.refworld.org/docid/3ae6ac1c30.html adresinden alındı

Robeyns, I. (2003). Sen's Capabilty Approach and Gender Inequality: Selecting relevant capabilities. Feminist Economics 9(2-3), s. 61-92.

Saigaran, Karupiah, Gopal. (2015). The Capability Approach: Comparing Amartya

Sen and Martha Nussbaum. USM International Social Sciences Conference 2015, elSBN 978-967-11473-3-7. Penang.

SE1. (2017, 2 1). Suriye'de ve Türkiye'de Hayat. (E. Topcu, Röportaj Yapan)

Sen, A. (1981). Poverty and famines: An Essay on Entitlement and Deprivation.

Oxford: Clarendon Press .

SEOG1. (2017, 5 30). Suriyeli Erkekler Odak Grup Görüșmesi. (E. Topcu, Röportaj Yapan)

SK1. (2017, 2 1). Suriye'de ve Türkiye'de Hayat. (E. Topcu, Röportaj Yapan)

SK1. (2017, 2 1). Suriye'de ve Türkiye'de Hayat. (E. Topcu, Röportaj Yapan)

SK10. (2017, 1 20). Suriyezde ve Türkiye'de Hayat. (E. Topcu, Röportaj Yapan)

SK12. (2016, 5 23). Suriye'de ve Türkiye'de Hayat. (E. Topcu, Röportaj Yapan)

SK13. (2016, 5 30). Suriye'de ve Türkiye'de Hayat. (E. Topcu, Röportaj Yapan)

SK14. (2016, 5 23). Suriye'de ve Türkiye'de Hayat. (E. Topcu, Röportaj Yapan)

SK15. (2016, 5 30). Suriye'de ve Türkiye'de Hayat. (E. Topcu, Röportaj Yapan)

SK16. (2016, 6 30). Suriye'de ve Türkiye'de Hayat. (E. Topcu, Röportaj Yapan)

SK16. (2016, 5 31). Suriye'de ve Türkiye'de Hayat. (E. Topcu, Röportaj Yapan)

SK16. (2016, 5 31). Suriye'de ve Türkiye'de Hayat. (E. Topcu, Röportaj Yapan)

SK17. (2017, 124). Suriye'de ve Türkiye'de Hayat. (E. Topcu, Röportaj Yapan)

SK17. (2017, 124). Suriye'de ve Türkiye'de Hayat. (E. Topcu, Röportaj Yapan)

SK18. (2017, 7 3). Suriye'de ve Türkiye'de Hayat. (E. Topcu, Röportaj Yapan)

SK19. (2017, 7 4). Suriye'de ve Türkiye'de Hayat. (E. Topcu, Röportaj Yapan)

SK2. (2017, 1 13). Suriye'de ve Türkiye'de Hayat. (E. Topcu, Röportaj Yapan)

SK2. (2017, 01 13). Suriye'de ve Türkiye'de Hayat, Suriyeli Kadın 2. (E. Topcu, Röportaj Yapan)

SK20. (2016, 6 22). Suriye'de ve Türkiye'de Hayat. (E. Topcu, Röportaj Yapan)

SK20. (2016, 6 22). Suriye'de ve Türkiye'de Hayat. (E. Topcu, Röportaj Yapan)

SK21. (2017, 5 17). Suriye'de ve Türkiye'de Hayat. (E. Topcu, Röportaj Yapan)

SK22. (2018, 04 22). Suriye'de ve Türkiye'de Hayat. (E. Topcu, Röportaj Yapan)

SK22. (2018, 04 22). Suriye'de ve Türkiye'de Hayat. (E. Topcu, Röportaj Yapan)

SK4. (2017, 1 27). Suriye'de ve Türkiye'de Hayat. (E. Topcu, Röportaj Yapan)

SK5. (2017, 4 21). Suriye'de ve Türkiye'de Hayat. (E. Topcu, Röportaj Yapan)

SK5. (2017, 4 21). Suriye'de ve Türkiye'de Hayat. (E. Topcu, Röportaj Yapan)

SK6. (2016, 5 30). Suriye'de ve Türkiye'de Hayat. (E. Topcu, Röportaj Yapan)

SK6. (2017, 3 10). Suriye'de ve Türkiye'de Hayat. (E. Topcu, Röportaj Yapan)

SK7. (2017, 1 27). Suriye'de ve Türkiye'de Hayat. (E. Topcu, Röportaj Yapan)

SK7. (2017, 1 27). Suriye'de ve Türkiye'de Hayat. (E. Topcu, Röportaj Yapan)

SK8. (2017, 3 10). Suriye'de ve Türkiye'de Hayat. (E. Topcu, Röportaj Yapan) 
SK8. (2017, 3 10). Suriye'de ve Türkiye'de Hayat. (E. Topcu, Röportaj Yapan)

SK9. (2017, 113). Türkiye'de ve Suriye'de Hayat. (E. Topcu, Röportaj Yapan)

SKOG1. (2017, 5 15). Suriyeli Kadın Odak Grup Görüşmesi 1. (E. Topcu, Röportaj Yapan)

SKOG2. (2017, 5 8). Suriyeli Kadın Odak grup Görüşmesi 2. (E. Topcu, Röportaj Yapan)

SKOG4. (2017, 5 9). Suriyeli Kadın Öğretmen Odak Grup Görüşmesi. (E. Topcu, Röportaj Yapan)

Somekh, B. (2006). Action Research: a Methodology for Change and Development. Berkshire: Open University Press.

TEÖ1. (2017, 2 24). Türk Erkek Öğretmen 1. (E. Topcu, Röportaj Yapan)

The World Bank Group (US). (2019). https://data.worldbank.org/indicator/SL.TLF.TOTL.FE.ZS adresinden alındı

TKÖ1. (2017, 5 12). Türk Kadın Öğretmen 1. (E. Topcu, Röportaj Yapan)

TKÖ2. (2017, 2 17). Türk Kadın Öğretmen 2. (E. Topcu, Röportaj Yapan)

TKÖ4. (2017, 3 17). Türk Kadın Öğretmen 4. (E. Topcu, Röportaj Yapan)

TKÖ4, T. K. (2017, 3 17). Suriyelilerle Tecrübeleri. (E. Topcu, Röportaj Yapan)

Topcu, E. (2017). The Changing Situation of Syrian Women in the Family and the Society Through the Solidarity Between Turkish and Syrian Women. W. K. Faris içinde, Muslim Women's Contributions to Society (s. 295-326). Kuala Lumpur: Centre for Muslim World Affairs International İslamic University .

Topcu, E. (2018). Female Leadership in the Framework of Crises Management within the Scope of Aid to the Syrians (An Example from Ankara). Middle East Journal of Refugee Studies, Vol: 3 Number: 1, DOI: 10.12738/mejrs.2018.3.1.0007, s. 41-52.

Topcu, E. (2018). Female Leadership in the Framework of Crises Management within the Scope of Aid to the Syrians (An Example from Ankara), . Middle East Journal of Refugee Studies, Vol: 3 Number: 1, DOI: 10.12738/mejrs.2018.3.1.0007, s. 41-52.

Topcu, E. Kurtulmuş, S. (2017). Türkiye'deki Suriyelilerle Çalışan Sivil Toplum Kuruluşları ve Gönüllülere Yönelik Etüt Çalışması: Gönüllüler Grubu Örnek Olay Incelemesi Ankara Örneği. Ankara: T.C. Aile ve Soyal Politikalar Bakanlığı.

UNFPA. (2010). Guidelines on Data Issues in Humanitarian Crisis Situations. UNFPA. UNICEF. (2012). UNICEF Syria: https://www.unicef.org/infobycountry/syria_statistics.html adresinden alındı 